\title{
Uncoupling protein 3 as a mitochondrial fatty acid anion exporter
}

Citation for published version (APA):

Schrauwen, P., Hoeks, J., Schaart, G., Kornips, C. F. P., Binas, B., van der Vusse, G. J., van Bilsen, M., Luiken, J. J. F. P., Coort, S. L. M., Glatz, J. F., Saris, W. H. M., \& Hesselink, M. K. C. (2003). Uncoupling protein 3 as a mitochondrial fatty acid anion exporter. Faseb Journal, 17(15), 2272-2274.

https://doi.org/10.1096/fj.03-0515fje

Document status and date:

Published: 01/01/2003

DOI:

10.1096/fj.03-0515fje

Document Version:

Publisher's PDF, also known as Version of record

\section{Please check the document version of this publication:}

- A submitted manuscript is the version of the article upon submission and before peer-review. There can be important differences between the submitted version and the official published version of record.

People interested in the research are advised to contact the author for the final version of the publication, or visit the DOI to the publisher's website.

- The final author version and the galley proof are versions of the publication after peer review.

- The final published version features the final layout of the paper including the volume, issue and page numbers.

Link to publication

\footnotetext{
General rights rights.

- You may freely distribute the URL identifying the publication in the public portal. please follow below link for the End User Agreement:

www.umlib.nl/taverne-license

Take down policy

If you believe that this document breaches copyright please contact us at:

repository@maastrichtuniversity.nl

providing details and we will investigate your claim.
}

Copyright and moral rights for the publications made accessible in the public portal are retained by the authors and/or other copyright owners and it is a condition of accessing publications that users recognise and abide by the legal requirements associated with these

- Users may download and print one copy of any publication from the public portal for the purpose of private study or research.

- You may not further distribute the material or use it for any profit-making activity or commercial gain

If the publication is distributed under the terms of Article $25 \mathrm{fa}$ of the Dutch Copyright Act, indicated by the "Taverne" license above, 
The FASEB Journal express article 10.1096/fj.03-0515fje. Published online October 2, 2003.

\section{Uncoupling protein 3 as a mitochondrial fatty acid anion exporter}

Patrick Schrauwen, ${ }^{*} J_{0}$ ris Hoeks, ${ }^{*}$ Gert Schaart, ${ }^{\dagger}$ Esther Kornips, ${ }^{* \dagger}$ Bert Binas, ${ }^{\S} \|$ Ger J. van de Vusse, ${ }^{\ddagger}$ Marc van Bilsen, ${ }^{\ddagger}$ Joost J.F.P. Luiken, ${ }^{\ddagger}$ Susan L. M. Coort, ${ }^{\ddagger}$ Jan F. C. Glatz, ${ }^{\dagger}$ Wim H. M. Saris, ${ }^{*}$ and Matthijs K. C. Hesselink ${ }^{\dagger}$

*Department of Human Biology, NUTRIM, Maastricht University, The Netherlands;

Department of Movement Sciences, NUTRIM, Maastricht University, The Netherlands;

${ }^{\dagger}$ Department of Physiology, CARIM, Maastricht University, The Netherlands; and ${ }^{\S}$ Department of Hypertension Research, Max Delbrück Center for Molecular Medicine, Berlin-Buch, Germany. "Present address: Department of Pathobiology, College of Veterinary Medicine, Texas A\&M University, Raymond Stotzer Pkwy, College Station Texas, 77843-4467.

Corresponding author: Patrick Schrauwen Nutrition and Toxicology Research Institute Maastricht (NUTRIM) Department of Human Biology, Maastricht University P.O. Box 616 NL6200 MD Maastricht, The Netherlands. E-mail: p.schrauwen@hb.unimaas.nl

\section{ABSTRACT}

In contrast to UCP1, the primary function of UCP3 is not the dissipation of energy. Rather, several lines of evidence suggest that UCP3 is related to cellular long-chain fatty acid homeostasis. If long-chain fatty acids enter the mitochondrial matrix in their non-esterified form, they cannot be metabolized and may exert deleterious effects. To test the feasibility that UCP3 exports fatty acid anions, we systematically interfered at distinct steps in the fatty acid metabolism pathway, thereby creating conditions in which the entry of (non-esterified) fatty acids into the mitochondrial matrix is enhanced. First, reducing the cellular fatty acid binding capacity, known to increase cytosolic concentrations of non-esterified fatty acids, up-regulated UCP3 5.3-fold. Second, inhibition of mitochondrial entry of esterified long-chain fatty acids upregulated UCP3 by 1.9-fold. Third, high-fat diets, to increase mitochondrial supply of nonesterified long-chain fatty acids exceeding oxidative capacity, up-regulated UCP3 twofold. However, feeding a similar amount of medium-chain fatty acids, which can be oxidized inside the mitochondrial matrix and therefore do not need to be exported from the matrix, did not affect UCP3 protein levels. These data are compatible with a physiological function of UCP3 in facilitating outward transport of long-chain fatty acid anions, which cannot be oxidized, from the mitochondrial matrix.

Key words: UCP3 $\bullet$ fatty acid transport $\bullet$ mitochondria $\bullet$ high-fat diet

I

$\mathrm{n}$ contrast to the brown adipose tissue-specific UCP1, there is ample evidence that the physiological function of UCP3 is not in energy dissipation. For example, fasting, an energy preserving condition, rapidly up-regulates UCP3 (1). We have recently demonstrated in humans that a diet-induced up-regulation of UCP3 did not affect mitochondrial coupling, suggesting that the primary function of UCP3 is not mitochondrial uncoupling (2). Rather, several lines of evidence suggest that UCP3 is related to cellular fatty acid metabolism. Thus, 
aberrations in whole-body fat oxidation were observed in humans with an exon-6 splice donor mutation in UCP3 (3), as well as in UCP3 knockout mice (4). Furthermore, in skeletal muscle UCP3 is rapidly up-regulated during fasting (1), acute exercise $(5,6)$, and high dietary fat-intake $(7,8)$, all situations in which fat metabolism is affected. In addition, UCP3 protein content declines in situations in which fat oxidative capacity is improved, such as after endurance training $(9,10)$ and after weight reduction $(11,12)$, and UCP3 has lowest expression in Type 1 muscle fibers, which are characterized by a high fat oxidative capacity $(13,14)$.

This pattern of regulation of UCP3 can consistently be explained by considering the balance between fatty acid delivery to mitochondria and their capacity to oxidize fatty acids. In situations characterized by a positive balance (i.e., fatty acid delivery exceeds oxidative capacity), such as fasting, high-fat intake, acute exercise, and in Type 2b fibers, UCP3 levels are high and/or upregulated. However, in situations characterized by a high fat oxidative capacity leading to a negative or zero balance (i.e., fatty acid delivery is lower than or balances oxidative capacity), such as training, weight reduction, and Type 1 muscle fibers, UCP3 levels are low and/or downregulated. Considering these findings, we have postulated the hypothesis that UCP3 might be involved in the export of non-esterified fatty acids from the mitochondrial matrix (15). Thus, when fatty acid delivery exceeds the muscle's oxidative capacity, fatty acids will accumulate inside the myocyte. To be diverted to $\beta$-oxidation, most of the long-chain fatty acids in the cytoplasm are activated by conversion to their fatty acyl-CoA esters by the enzyme long-chain acyl-CoA synthetase (ACS). Subsequently, these long-chain fatty acyl-CoA esters are transported into the mitochondria via the carnitine shuttle system (CPT1 and CPT2). Only as CoA esters, fatty acids can undergo $\beta$-oxidation, and the esterification of fatty acids and subsequent transport across the inner membrane is rate-limiting in the oxidation of long-chain fatty acids. The surplus of long-chain fatty acids that accumulate inside the myocyte may enter the mitochondria by a so-called flip-flop mechanism (16). Due to the higher $\mathrm{pH}$ inside the mitochondrial matrix, part of these long-chain fatty acids will be deprotonated at the matrix side and, in this way, fatty acid anions can reach the mitochondrial matrix. It is important to note that, once inside the matrix, these long-chain fatty acid anions can neither be diverted to $\beta$-oxidation (due to lack of ACS inside the matrix) nor cross the inner mitochondrial membrane (17) and are thus trapped inside the mitochondria. Here, they can have deleterious effects on mitochondrial function, for example due to their amphiphilic nature and proneness to peroxidation. Here, UCP3 could become involved in facilitating outward transport of these fatty acid anions, as it has been shown that UCP3 can transport fatty acid anions $(18,19)$.

To test the feasibility that UCP3 functions to export fatty acid anions away from the matrix, we systematically interfered at distinct steps in the pathway of fatty acid metabolism - thereby creating conditions in which the entry of (non-esterified) fatty acids into the mitochondrial matrix is enhanced-and we examined UCP3 protein content in these situations.

\section{MATERIALS AND METHODS}

\section{Animals}

All studies were approved by the Institutional Animal Care and Use Committee of the Maastricht University and complied with the principles of laboratory animal care. Animals were housed individually on a 12:12 h light-dark cycle (light from 7:00 a.m. to 7:00 p.m.), at $21-22^{\circ} \mathrm{C}$ and allowed unlimited access to standard chow diet. 
To examine the effect of the absence of H-FABP on UCP3 protein content (Experiment 1), adult (10-12 months of age) mice lacking H-FABP $(n=5)$ and their wild-type littermates $(n=7)$ were used, as described previously (20). Under general anesthesia [1.5-2.0\% halothane in $\mathrm{O}_{2}$ and $\mathrm{N}_{2} \mathrm{O}$ $\left.\left(3: 1,4.01 \cdot \mathrm{min}^{-1}\right)\right]$, medial gastrocnemius muscles were rapidly excised unilaterally and were freeze-clamped within $7 \mathrm{~s}$ after cutting the nerve and blood vessels.

The effect of etomoxir administration on UCP3 protein content was studied in 12 male Lewis rats, weighing 210-220 g (Experiment 2). Rats were divided randomly into etomoxir and control group. The former group was treated with etomoxir dissolved in $0.9 \% \mathrm{NaCl}(20 \mathrm{mg} / \mathrm{kg}$ bodyweight) intraperitoneally for 8 days. The final injection was given $24 \mathrm{~h}$ before the experiment. Animals were anesthetized with an intraperitoneal injection of Nembutal, and their left hind limb muscles were removed.

The effect of high-fat diets on UCP3 protein content was studied in 30 male, 10-week-old Wistar rats (Experiment 3$)$. Rats were randomly divided into three different groups $(n=10)$, receiving either low-fat control (low-fat), high-fat medium-chain triglyceride (high-fat MCT), or high-fat long-chain triglyceride (high-fat LCT) diets. Rats were fed ad libitum and had free access to tap water during the experimental period. Food intakes were recorded daily at 8:30 a.m., and body weight was measured twice a day at 8:30 a.m. and 5:30 p.m. After a two-week diet-intervention period, blood was sampled and medial gastrocnemius muscle was rapidly excised unilaterally and freeze-clamped within $7 \mathrm{~s}$ after cutting the nerve and blood vessels under general anesthesia. Rats were deprived from food $\sim 6 \mathrm{~h}$ prior to tissue sampling.

\section{Diets}

The H-FABP mice and the rats in the etomoxir experiment had ad libitum access to standard lab chow (Hope Farms, Woerden, the Netherlands).

In Experiment 3, rats were given the following: low-fat diets consisted of 7 energy $\%$ fat (of which approx. 79\% C16:0, 6\% C18:0, and 12\% C18:1) and 74 energy \% carbohydrate. High-fat LCT diets consisted of 46 energy \% fat (of which approx. 79\% C16:0, 6\% C18:0, and 12\% C18:1) and 35 energy \% carbohydrates. High-fat MCT diets consisted of 46 energy \% fat (of which approx. 60\% C8:0 and 40\% C10:0) and 35 energy \% carbohydrates. Protein content was constant in all diets (19 en\%). All diets were purchased from Hope Farms (Woerden, The Netherlands).

\section{CPT-1 activity}

Muscle $(50 \mathrm{mg})$ was homogenized in $1 \mathrm{ml}$ of TES $(10 \mathrm{mM}$ Tris-HCL, $2 \mathrm{mM}$ diNaEDTA, 250 $\mathrm{mM}$ sucrose, $\mathrm{pH}$ 7.4)-buffer supplemented with phenylmethylsulfonyl fluoride (PMSF)dimethyl sulfoxide (DMSO) and homogenized with an Ultra Turrax homogenizer (Janke \& Kunkel, Ika-Labortechnik, Staufen, Germany). The resulting muscle homogenate was disintegrated further in four cycles ( $5 \mathrm{~s}$ on, $15 \mathrm{~s}$ off) with an amplitude of 10-12 using an ultrasonic disintegrator. CPT-1 activity was assayed by the CPT-forward measurement (21). This method measures the palmitoylcarnitine formation from palmitoyl-CoA and an adenosine trisphosphate (ATP) regenerating system. The reaction mixture contained $10 \mu \mathrm{M}$ palmitoyl-CoA, $0.25 \mathrm{mM} \mathrm{L}\left[{ }^{3} \mathrm{H}\right]$ carnitine, $80 \mathrm{mM}$ Tris- $\mathrm{HCl}, 2 \mathrm{mM}$ ATP, $2.5 \mathrm{mM} \mathrm{MgCl}_{2}, 0.25 \mathrm{mM}$ Na-palmitate, $36 \mu \mathrm{M}$ bovine serum albumin (BSA), $0.5 \mathrm{mM}$ DTA, $1 \mathrm{mM} \mathrm{KCN}, 0.5 \mathrm{mM}$ dithiothreitol, $5 \mathrm{mM}$ 
phosphoenolpyruvate, $2.5 \mu \mathrm{g}$ pyruvate kinase, $1 \mu \mathrm{g}$ adenylate kinase, and $10 \mu \mathrm{l}$ homogenate. Incubation was performed at $\mathrm{pH} 7.4$, in a total volume of $0.25 \mathrm{ml}$ for $10 \mathrm{~min}$ at $37^{\circ} \mathrm{C}$. The reaction was started with carnitine and terminated with $1 \mathrm{ml} 1 \mathrm{M} \mathrm{HCl}$. The product palmitoyl$\mathrm{L}\left[{ }^{3} \mathrm{H}\right]$ carnitine was extracted with $1 \mathrm{ml}$ butanol. After $30 \mathrm{~s}$ of mixing and centrifugation $(3000 \mathrm{~g})$ for $5 \mathrm{~min}$, the upper butanol phase was washed with $2 \mathrm{ml} \mathrm{H}_{2} \mathrm{O}$ saturated with butanol. After $30 \mathrm{~s}$ mixing and centrifugation $(3000 \mathrm{~g})$, radioactivity was measured in $0.4 \mathrm{ml}$ of the butanol with 10 $\mathrm{ml}$ instagel in a liquid scintillation counter.

\section{UCP3 protein measurement}

Muscle samples for UCP3 protein content were homogenized in ice-cold phosphate buffered saline (PBS), containing $1 \mathrm{mM}$ ethylene diamine tetraacetate (EDTA) and 0,4 mM PMSF and subsequently sonicated for 3 times $10 \mathrm{~s}$. After sonication, two volumes of each skeletal muscle homogenate and one volume of SDS-sample buffer (22) were boiled for $4 \mathrm{~min}$. Thereafter, samples were centrifuged for $5 \mathrm{~min}$ at $10,000 \mathrm{~g}$. Total protein content of each sample was measured spectrophotometrically (protein assay, Bio-Rad Laboratories, Hercules, CA) to ensure that equal amounts of protein were loaded. Samples were loaded on 13\% polyacrylamide slab gels containing $0,1 \%$ SDS, and electrophoresis was performed by using a Mini-Protean 3 Electrophoresis Cell (Bio-Rad Laboratories), followed by Western blotting with a Mini TransBlot Electrophoretic Transfer Cell (Bio-Rad Laboratories). The separated polypeptides were transferred to a nitrocellulose membrane by blotting for $1 \mathrm{~h}$ at $100 \mathrm{~V}$ in a cold buffer containing $25 \mathrm{mM}$ Tris, $192 \mathrm{mM}$ glycine, and 20\% methanol.

After protein transfer, nitrocellulose sheets were blocked with blocking buffer, containing 5\% nonfat dry milk and $0.05 \%$ Tween 20 in PBS, for at least 20 min. Thereafter, antibody incubation was performed by gentle shaking overnight at room temperature at a dilution of 1:5000 in blocking buffer. We used an affinity-purified rabbit polyclonal antibody against UCP3 (Code 1338, kindly provided by L. J. Slieker, Eli Lilly and Co. (Indianapolis, IN). After being washed with $0.05 \%$ Tween 20 in PBS, blots were incubated with horseradish peroxidase-conjugated swine anti-rabbit Ig (SWARPO, DAKO, Glostrup, Denmark) for $60 \mathrm{~min}$ at room temperature, diluted 1:10,000 in blocking buffer. Blots were subsequently washed for 90 min with $0,05 \%$ Tween 20 in PBS, and 10 min in PBS. Chemiluminescence was performed by using a Super Signal West Dura Extended kit (Pierce, Rockford, IL). Finally, the reaction product of each blot

was analyzed by densiometry using Imagemaster (Pharmacia Biotech, Roosendaal, The Netherlands).

\section{Plasma FFA}

Frozen deproteinized plasma samples were analyzed for total free fatty acids (FFA) by using the Wako NEFA C test kit (Wako Chemicals, Neuss, Germany).

\section{Statistical analysis}

Results are presented as mean \pm SE. Differences between groups were evaluated by ANOVA (one-way ANOVA test). When significant differences were found, a Bonferroni adjusted post hoc test was used to determine the exact location of the difference. Outcomes were regarded statistically significant if $P<0.05$. 


\section{RESULTS}

\section{Experiment 1}

UCP3 protein levels in skeletal muscle of H-FABP null mice were increased 5.3-fold compared with their wild-type littermates $(529 \pm 99$ vs. $100 \pm 38$ arbitrary units in H-FABP null $(n=5)$ and wild-type littermates $(n=7)$, respectively, $P<0.05$, Fig. $1 a)$.

\section{Experiment 2}

Etomoxir significantly decreased CPT1 activity by 58\% in the etomoxir group, indicating effective blockade of mitochondrial uptake of long-chain fatty acyl-CoA esters ( $8.8 \pm 2.1$ vs. $3.3 \pm 2.2 \mathrm{mU} / \mathrm{g}$ wet mass in control and etomoxir, respectively, $n=6, P<0.05)$. In accordance with our hypothesis, we found that UCP3 protein levels were increased 1.9-fold after etomoxir administration $(100 \pm 35$ vs. $189 \pm 59$ arbitrary units in control and etomoxir, respectively, $n=6$, $P<0.05$, Fig. $1 b)$.

\section{Experiment 3}

Food intake was similar in the three groups $(4.23 \pm 0.08,3.96 \pm 0.12$, and $4.21 \pm 0.09 \mathrm{MJ} / 2$ weeks on low-fat, high-fat MCT, and high-fat LCT, respectively, NS). However, body weight increased more pronouncedly on the high-fat LCT compared with the high-fat MCT and low-fat groups $(53.0 \pm 1.5$ vs. $44.6 \pm 2.9$ and $45.3 \pm 1.0 \mathrm{~g} / 2$ weeks on high-fat LCT vs. high-fat MCT and low-fat, respectively, $P<0.05)$. In accordance with our hypothesis, the high-fat LCT diet resulted in an up-regulation of UCP3 protein content by twofold (201 \pm 36 vs. $100 \pm 22$ arbitrary units on high-fat LCT vs. low-fat, respectively, $n=10, P<0.05$, Fig. $1 c$ ). The up-regulation of UCP3, as observed on a high-fat long-chain fatty acid diet, was completely absent when the high-fat diet was provided in the form of medium-chain fatty acids (86 \pm 17 vs. $100 \pm 22$ arbitrary units on high-fat MCT vs. low-fat, respectively, $n=10, P>0.05$, Fig. $1 d$ ). The lack of up-regulation of UCP3 in the medium-chain group vs. the long-chain group could not be explained by differences in plasma free fatty acid concentrations $(201 \pm 20,249 \pm 34$, and $274 \pm 26 \mu \mathrm{mol} / 1$ on low-fat, high-fat MCT, and high-fat LCT, respectively, $n=10, P>0.05)$.

\section{DISCUSSION}

Soon after the discovery of human UCP3, several observations indicated that the primary physiological role of UCP3 is not the regulation of energy turnover (2), as would be predicted from its homology to UCP1. Thus, mice lacking UCP3 have a normal metabolic rate and body weight $(23,24)$, and fasting, an energy preserving condition, rapidly up-regulates the expression of UCP3 (1). Rather, several groups suggested a role for UCP3 in fatty acid handling (1, 3, 7, 13). Here we provide evidence for a new physiological function of UCP3 (15) as an outward transporter of long-chain fatty acid anions from the mitochondrial matrix into the soluble cytoplasm (Fig. 2). By doing so, UCP3 prevents accumulation of non-esterified fatty acids that entered the mitochondrial matrix by so-called flip-flop across the mitochondrial inner membrane, especially in conditions in which the entry of non-esterified fatty acids into the mitochondrial matrix is enhanced.

After being taken up into the muscle cell, most fatty acids inside the soluble cytoplasm are bound to heart-type fatty-acid binding protein (H-FABP or FABPc). The water solubility of fatty 
acids (4-6 $\mu \mathrm{M}$; Ref. 16) exceeds the affinity of H-FABP for fatty acids (4-14 nM; ref: 25$)$ by far, indicating an important role for H-FABP in controlling the intracellular unbound fatty acid concentration in order to maintain a fatty acid gradient between plasma/interstitium and cytoplasm to facilitate fatty acid uptake (25-27). Lack of H-FABP would thus lead to an intracellular increase of unbound fatty acids, particularly because plasma fatty acid levels are elevated in these mice as well (28). In addition, the presence of H-FABP was shown to be crucial for proper mitochondrial oxidation of fatty acids (20), as H-FABP is suggested to be essential for activation (esterification) of fatty acids by interacting with long-chain ACS (29). Therefore, in mice lacking H-FABP the fraction unbound fatty acids in the cytoplasm will be increased while esterification of fatty acids by ASC will be diminished. Here, we have used mice lacking HFABP to increase the intracellular concentration of unbound (non-esterified) fatty acids. Especially in the unbound form these fatty acids rapidly incorporate into (mitochondrial) membranes, and could reach the mitochondrial matrix. The pronounced up-regulation of UCP3 protein in these mice therefore fits our hypothesis that UCP3 is needed to facilitate outward transport of fatty acid anions.

To provide further evidence for a physiological function of UCP3 in fatty acid anion export, we interfered more distally in the fatty acid oxidation pathway. The rate-limiting step in the mitochondrial uptake and oxidation of fatty acids is their esterification to fatty acyl-CoA and subsequent transport across the inner mitochondrial membrane after conversion into acylcarnitine through the catalyzing action of carnitine-palmitoyl -transferase-1 (CPT1). Therefore, blocking the main route for mitochondrial transport of long-chain fatty acyl-CoA esters will lead to accumulation of cellular non-esterified fatty acids, which could then enter the mitochondrial matrix. The observed up-regulation of UCP3 upon inhibition of CPT1 activity, again, is in accordance with a role of UCP3 in fatty acid anion export. Clearly, blocking mitochondrial entry of long-chain fatty acids decreases mitochondrial substrate availability. If the primary role of UCP3 were to regulate energy dissipation, it would be anticipated that during decreased substrate availability, UCP3 would be down-regulated rather than markedly increased, as was observed in the present study. Thus, increased expression of UCP3 after blocking CPT1 is inconsistent with a primary role of UCP3 in energy dissipation. In addition, increased UCP3 following blockade of CPT1 does not match with a role for UCP3 in the oxidation of fatty acids, indicating that the physiological function of UCP3 is in a different step in the pathway of fatty acid metabolism.

In a more physiological approach to increase the entry of non-esterified fatty acids into the mitochondrial matrix, while not interfering with mitochondrial oxidative capacity, we used highfat diets to oversupply fatty acids to mitochondria. With high-fat feeding, the continuous delivery of fatty acids exceeds the oxidative capacity and not all fatty acids can be oxidized, resulting in a transient accumulation of fatty acids inside the muscle cell (30). Under such conditions, the entry of non-esterified fatty acids into the mitochondrial matrix will increase and the observed high-fat induced up-regulation of UCP3 may serve to facilitate outward transport of these fatty acids from the matrix. In contrast to long-chain fatty acids, medium-chain fatty acids do not need to be esterified to CoA esters in the cytoplasm. Medium-chain fatty acids bypass the control of mitochondrial transport by CPT1 and, in contrast to long-chain fatty acids, mediumchain fatty acids can be esterified to their respective CoA esters inside the mitochondrial matrix and can therefore still be diverted to $\beta$-oxidation $(31,32)$. On a high-fat diet consisting of medium-chain fatty acids there would be no need to up-regulate UCP3, as the majority of fatty acids that enter the matrix will be of medium-chain length and thus can still be diverted to $\beta$ - 
oxidation once inside the matrix. The lack of up-regulation of UCP3 on the medium-chain highfat diet vs. the long-chain high-fat diet, despite similar plasma non-esterified fatty acid levels, therefore supports the hypothesis that UCP3 is specifically involved in the export of nonesterified long-chain fatty acid anions from the mitochondrial matrix into soluble cytoplasm. Moreover, upon entering the $\beta$-oxidation, the metabolism of fatty acids is independent of chain length, suggesting that the physiological function of UCP3 is not related to fatty acid metabolism distal from $\beta$-oxidation.

A role for UCP3 as an exporter of fatty acid anions has also been proposed by Himms-Hagen et al. (33). They hypothesize that, once inside the mitochondrial matrix in their esterified form, not all fatty acyl-CoA esters are diverted toward $\beta$-oxidation but that some may be hydrolyzed by a mitochondrial thioesterase (MTE1), resulting in non-esterified fatty acids and CoA. Again, due to the lack of long-chain ACS within the mitochondrial matrix, outward transport of nonesterified fatty acid is preferred and UCP3 is the protein hypothesized to be responsible. Although the pronounced up-regulation of UCP3 upon etomoxir administration is not compatible with the hypothesis of Himms-Hagen, we cannot exclude that UCP3 also serves to export fatty acid anions derived from fatty acyl-CoA hydrolysis. Regardless the origin of the fatty acid anion within the matrix (either flip-flop across the inner mitochondrial membrane or by hydrolyses of fatty acyl-CoA by a mitochondrial thioesterase), both hypotheses propose that the primary role of UCP3 is the outward translocation of fatty acids away from the mitochondrial matrix.

Export of non-esterified fatty acids from the mitochondrial matrix might be of physiological importance to prevent mitochondrial damage, as non-esterified fatty acids are prone to lipid peroxidation. In this context, it is important to note that it was recently found that mice lacking UCP3 indeed have increased lipid peroxidation (34). Furthermore, UCP3 protein content is decreased in Type 2 diabetic subjects (35), who were found to be more susceptible to mitochondrial DNA damage in skeletal muscle (36). Moreover, the decreased UCP3 protein content in diabetic patients, together with the generally observed accumulation of lipids inside the myocytes of Type 2 diabetics, might be an explanation for the impaired mitochondrial functioning in Type 2 diabetes (37), which could lead to the development of skeletal muscle insulin resistance, although further studies are needed to test this concept. In addition, accumulation of fatty acids inside the mitochondrial matrix might lead to disturbances in fatty acid oxidation, explaining the reported aberrations in fat oxidation in humans with the exon 6 splice donor mutation (3) and in UCP3 knockout mice (4).

In summary, we have provided evidence that the physiological function of UCP3 is the outward transport of fatty acid anions. Interference in successive steps in fatty acid handling, transport, and oxidation revealed that UCP3 is not directly involved in fatty acid oxidation. Rather, we showed that UCP3 protein increases if the supply of fatty acids to the mitochondria exceeds fat oxidative capacity, making it feasible that the physiological function of UCP 3 indeed is in fatty acid anion export. Although we realize that none of the experiments presented provide direct and definitive proof for our hypothesis, we interpret these data as compelling circumstantial evidence that UCP3 indeed facilitates outward translocation of fatty acids from the mitochondrial matrix. Definitive proof for the hypothesis awaits the development of methodology to measure mitochondrial fatty acid anion accumulation and/or transport. 


\section{ACKNOWLEDGMENTS}

The research of P. S. has been made possible by a fellowship of the Royal Netherlands Academy of Arts and Sciences. J. H. was supported by a grant from the Netherlands Organization for Scientific Research (NWO), and J.J.F.P. L. by a VIDI-Innovational Research grant from the Netherlands Organization for Scientific Research. S. C. was supported by the Netherlands Heart Foundation (Grant 2000.156). We thank Lawrence J. Slieker from Eli Lilly and Company for providing us with the UCP3 antibody, H.P.O. Wolf, Allensbach, Germany, for providing etomoxir, and H.E.C. Niessen for help with the etomoxir studies.

\section{REFERENCES}

1. Millet, L., Vidal, H., Andreelli, F., Larrouy, D., Riou, J.-P., Ricquier, D., Laville, M., and Langin, D. (1997) Increased uncoupling protein-2 and -3 mRNA expression during fasting in obese and lean humans. J. Clin. Invest. 100, 2665-2670

2. Hesselink, M. K. C., Greenhaff, P. L., Constantin-Teodosiu, D., Hultman, E., Saris, W. H. M., Nieuwlaat, R., Schaart, G., Kornips, E., and Schrauwen, P. (2003) Increased uncoupling protein 3 content does not affect mitochondrial function in human skeletal muscle in vivo. $J$. Clin. Invest. 111, 479-486

3. Argyropoulos, G., Brown, A. M., Willi, S. M., Zhu, J., He, Y., Reitman, M., Geveo, S. M., Spruill, I., and Garvey, W. T. (1998) Effects of mutations in the human uncoupling protein 3 gene on the respiratory quotient and fat oxidation in severe obesity and type 2 diabetes. $J$. Clin. Invest. 102, 1345-1351

4. Bezaire, V., Hofmann, W., Kramer, J. K., Kozak, L. P., and Harper, M. E. (2001) Effects of fasting on muscle mitochondrial energetics and fatty acid metabolism in Ucp3(-/-) and wild-type mice. Am. J. Physiol. Endocrinol. Metab. 281, E975-E982

5. Tsuboyama-Kasaoka, N., Tsunoda, N., Maruyama, K., Takahashi, M., Kim, H., Ikemoto, S., and Ezaki, O. (1998) Up-regulation of uncoupling protein 3 (UCP3) mRNA by exercise training and down-regulation of UCP3 by denervation in skeletal muscles. Biochem. Biophys. Res. Commun. 247, 498-503

6. Schrauwen, P., Hesselink, M. K., Vaartjes, I., Kornips, E., Saris, W. H., Giacobino, J. P., and Russell, A. (2002) Effect of acute exercise on uncoupling protein 3 is a fat metabolismmediated effect. Am. J. Physiol. Endocrinol. Metab. 282, E11-E17

7. Weigle, D. S., Selfridge, L. E., Schwartz, M. W., Seeley, R. J., Cummings, D. E., Havel, P. J., Kuijper, J. L., and BertrandelRio, H. (1998) Elevated free fatty acids induce uncoupling protein 3 expression in muscle. A potential explanation for the effect of fasting. Diabetes $\mathbf{4 7}$, 298-302

8. Schrauwen, P., Hoppeler, H., Billeter, R., Bakker, A. H., and Pendergast, D. R. (2001) Fiber type dependent upregulation of human skeletal muscle UCP2 and UCP3 mRNA expression by high-fat diet. Int. J. Obes. Relat. Metab. Disord. 25, 449-456 
9. Boss, O., Samec, S., Desplanches, D., Mayet, M.-H., Seydoux, J., Muzzin, P., and Giacobino, J.-P. (1998) Effect of endurance training on mRNA expression of uncoupling proteins 1,2 and 3 in the rat. FASEB J. 12, 335-339

10. Schrauwen, P., Troost, F. J., Xia, J., Ravussin, E., and Saris, W. H. (1999) Skeletal muscle UCP2 and UCP3 expression in trained and untrained male subjects. Int. J. Obes. Relat. Metab. Disord. 23, 966-972

11. Vidal-Puig, A., Rosenbaum, M., Considine, R. C., Leibel, R. L., Dohm, G. L., and Lowell, B. B. (1999) Effects of obesity and stable weight reduction on UCP2 and UCP3 gene expression in humans. Obes. Res. 7, 133-140

12. Schrauwen, P., Schaart, G., Saris, W. H., Slieker, L. J., Glatz, J. F., Vidal, H., and Blaak, E. E. (2000) The effect of weight reduction on skeletal muscle UCP2 and UCP3 mRNA expression and UCP3 protein content in Type II diabetic subjects. Diabetologia 43, 14081416

13. Samec, S., Seydoux, J., and Dulloo, A. G. (1998) Role of UCP homoloques in skeletal muscles and brown adipose tissue: mediators of thermogenesis or regulators of lipids as fuel substrate? FASEB J. 12, 715-724

14. Hesselink, M. K., Keizer, H. A., Borghouts, L. B., Schaart, G., Kornips, C. F., Slieker, L. J., Sloop, K. W., Saris, W. H., and Schrauwen, P. (2001) Protein expression of UCP3 differs between human type 1 , type $2 \mathrm{a}$, and type $2 \mathrm{~b}$ fibers. FASEB J. 15, 1071-1073

15. Schrauwen, P., Saris, W. H., and Hesselink, M. K. (2001) An alternative function for human uncoupling protein 3: protection of mitochondria against accumulation of nonesterified fatty acids inside the mitochondrial matrix. FASEB J. 15, 2497-2502

16. Hamilton, J. A., and Kamp, F. (1999) How are free fatty acids transported in membranes? Is it by proteins or by free diffusion through the lipids? Diabetes 48, 2255-2269

17. Jezek, P., Orosz, D. E., Modriansky, M., and Garlid, K. D. (1994) Transport of anions and protons by the mitochondrial uncoupling protein and its regulation by nucleotides and fatty acids. A new look at old hypotheses. J. Biol. Chem. 269, 26184-26190

18. Skulachev, V. P. (1999) Anion carriers in fatty acid-mediated physiological uncoupling. $J$. Bioenerg. Biomembr. 31, 431-445

19. Jezek, P., Engstová, H., Zácková, M., Vercesi, A. E., Costa, A. D. T., Arruda, P., and Garlid, K. D. (1998) Fatty acid cycling mechanism and mitochondrial uncoupling proteins. Biochim. Biophys. Acta 1365, 319-327

20. Schaap, F. G., Binas, B., Danneberg, H., van der Vusse, G. J., and Glatz, J. F. (1999) Impaired long-chain fatty acid utilization by cardiac myocytes isolated from mice lacking the heart-type fatty acid binding protein gene. Circ. Res. 85, 329-337 
21. Scholte, H. R., Jennekens, F. G., and Bouvy, J. J. (1979) Carnitine palmitoyltransferase II deficiency with normal carnitine palmitoyltransferase I in skeletal muscle and leucocytes. $J$. Neurol. Sci. 40, 39-51

22. Laemmli, U. K. (1970) Cleavage of structural proteins during the assembly of the head of bacteriophage T4. Nature 227, 680-685

23. Gong, D. W., Monemdjou, S., Gavrilova, O., Leon, L. R., Marcus-Samuels, B., Chou, C. J., Everett, C., Kozak, L. P., Li, C., and Deng, C. (2000) Lack of obesity and normal response to fasting and thyroid hormone in mice lacking uncoupling protein-3. J. Biol. Chem. 275, $16251-16257$

24. Vidal-Puig, A. J., Grujic, D., Zhang, C. Y., Hagen, T., Boss, O., Ido, Y., Szczepanik, A., Wade, J., Mootha, V., and Cortright, R. (2000) Energy metabolism in uncoupling protein 3 gene knockout mice. J. Biol. Chem. 275, 16258-16266

25. Glatz, J. F., and van der Vusse, G. J. (1996) Cellular fatty acid-binding proteins: their function and physiological significance. Prog. Lipid Res. 35, 243-282

26. Van der Vusse, G. J., and Roemen, T. H. (1995) Gradient of fatty acids from blood plasma to skeletal muscle in dogs. J. Appl. Physiol. 78, 1839-1843

27. Vusse G.J.v.d., and Reneman, R. S. (1996) Lipid metabolism in muscle. In Handbook of Physiology: Integration of Motor, Circulatory, Respiratory, and Metabolic Control During Exercise, (L. B. Rowell and J. T. Shepherd, Eds.) American Physiology Society, Bethesda: MD. 952-994

28. Binas, B., Danneberg, H., McWhir, J., Mullins, L., and Clark, A. J. (1999) Requirement for the heart-type fatty acid binding protein in cardiac fatty acid utilization. FASEB J. 13, 805812

29. Veerkamp, J. H., and van Moerkerk, H. T. (1993) Fatty acid-binding protein and its relation to fatty acid oxidation. Mol. Cell. Biochem. 123, 101-106

30. Bachmann, O. P., Dahl, D. B., Brechtel, K., Machann, J., Haap, M., Maier, T., Loviscach, M., Stumvoll, M., Claussen, C. D., and Schick, F. (2001) Effects of intravenous and dietary lipid challenge on intramyocellular lipid content and the relation with insulin sensitivity in humans. Diabetes 50, 2579-2584

31. Greenberger, N. J., and Skillman, T. G. (1969) Medium-chain triglycerides. N. Engl. J. Med. 280, $1045-1058$

32. McGarry, J. D., and Foster, D. W. (1980) Regulation of hepatic fatty acid oxidation and ketone body production. Annu. Rev. Biochem. 49, 395-420

33. Himms-Hagen, J., and Harper, M. E. (2001) Physiological role of UCP3 may be export of fatty acids from mitochondria when fatty acid oxidation predominates: an hypothesis. Exp. Biol. Med. (Maywood) 226, 78-84 
34. Brand, M. D., Pamplona, R., Portero-Otin, M., Requena, J. R., Roebuck, S. J., Buckingham, J. A., Clapham, J. C., and Cadenas, S. (2002) Oxidative damage and phospholipid fatty acyl composition in skeletal muscle mitochondria from mice underexpressing or overexpressing uncoupling protein 3. Biochem. J. 368, 597-603

35. Schrauwen, P., Hesselink, M. K., Blaak, E. E., Borghouts, L. B., Schaart, G., Saris, W. H., and Keizer, H. A. (2001) Uncoupling protein 3 content is decreased in skeletal muscle of patients with type 2 diabetes. Diabetes 50, 2870-2873

36. Liang, P., Hughes, V., and Fukagawa, N. K. (1997) Increased prevalence of mitochondrial DNA deletions in skeletal muscle of older individuals with impaired glucose tolerance: possible marker of glycemic stress. Diabetes 46, 920-923

37. Kelley, D. E., He, J., Menshikova, E. V., and Ritov, V. B. (2002) Dysfunction of mitochondria in human skeletal muscle in type 2 diabetes. Diabetes 51, 2944-2950

Received June 20, 2003; accepted August 14, 2003. 
Fig. 1
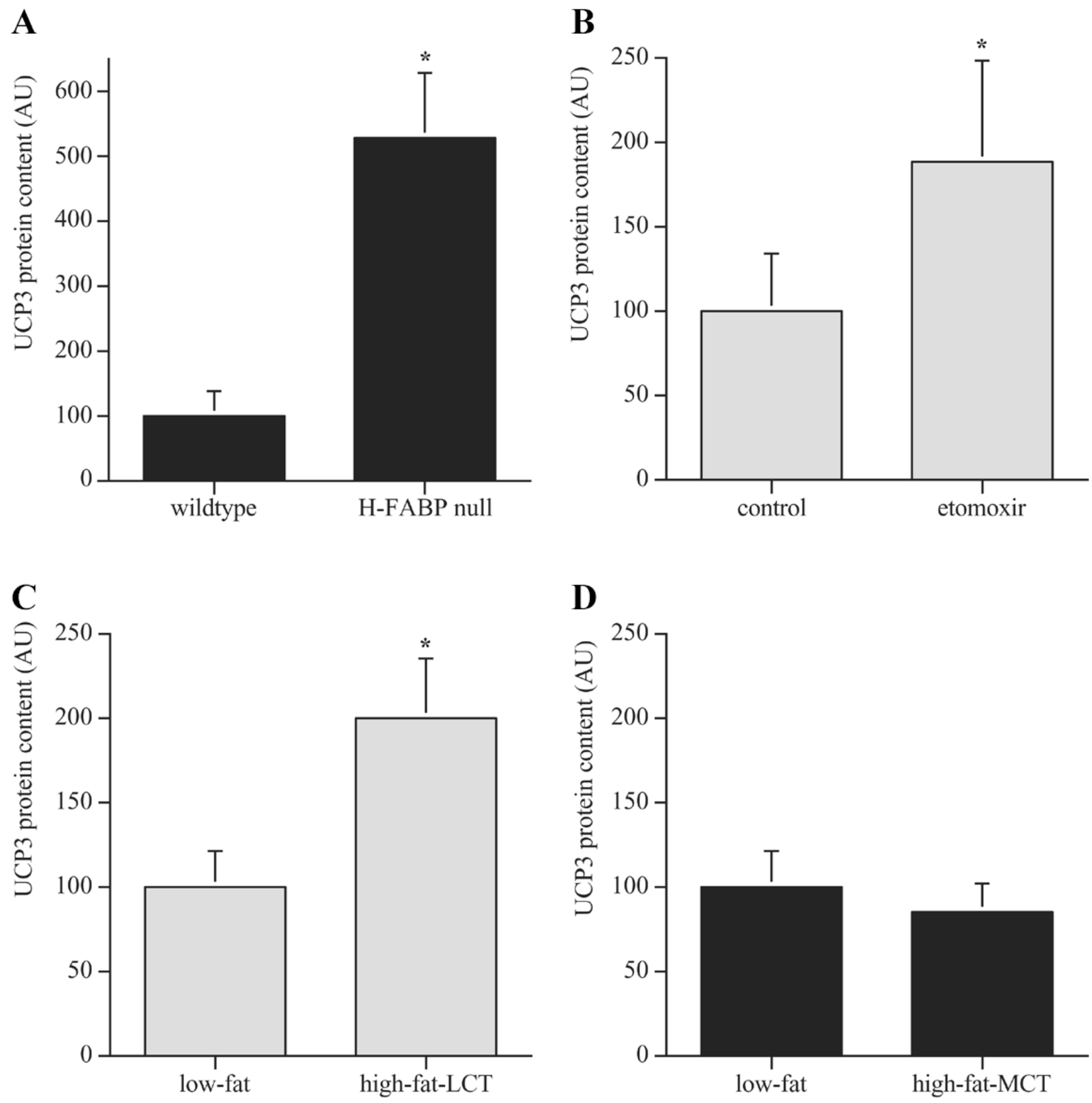

Figure 1. The effect of $\boldsymbol{a}$ ) absence of H-FABP, $\boldsymbol{b}$ ) administration of etomoxir, $\boldsymbol{c}$ ) feeding of a high-fat diet rich in longchain fatty acids, and $\boldsymbol{d}$ ) feeding of a high-fat diet rich in medium-chain fatty acids on UCP3 protein content. Control values are normalized to 100 arbitrary units. UCP3 is systematically up-regulated when the entry of long-chain fatty acids into the mitochondrial matrix is enhanced. ${ }^{*} P<0.05$ compared with control. 
Fig. 2

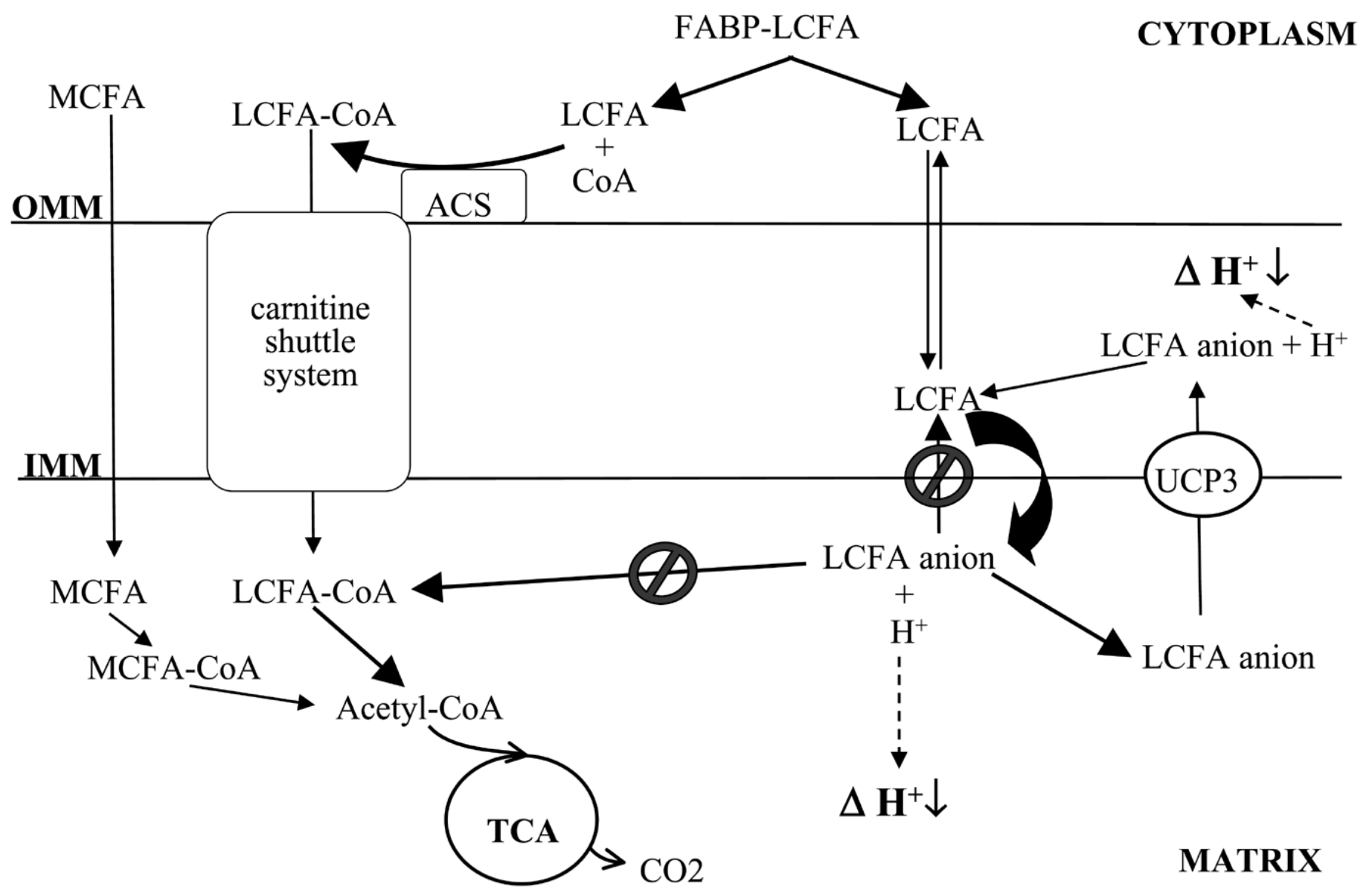

Figure 2. Schematic model of the putative function of UCP3. UCP3 protein content is increased in conditions in which the entry of long-chain fatty acids into the mitochondrial matrix is enhanced: 1) in H-FABP null mice, which are characterized by enhanced unbound cytoplasmic fatty acid concentrations and decreased capacity to activate fatty acids via ACS, 2) after inhibition of the carnitine shuttle system using etomoxir, and 3) on a high-fat diet, associated with increased supply of fatty acids to the mitochondria. Note that a high-fat diet rich in medium-chain fatty acids does not increase UCP3 protein content. Medium-chain fatty acids can enter the mitochondrial matrix in their non-esterified form, but can still be oxidized due to the presence of a medium-chain acyl-CoA synthetase inside the matrix. In the latter situation, UCP3 would not be needed for export of fatty acids. OMM, outer mitochondrial membrane; IMM, inner mitochondrial membrane; FA, fatty acid; TCA, tricarboxylic acid cycle. 